\title{
The Effect of Jigsaw Technique on the Students' Laboratory Material Recognition and Usage Skills in General Physics Laboratory-I Course ${ }^{\mathrm{i}}$
}

\author{
Abdullah Aydin ${ }^{1, *}$, Filiz Biyikli \\ ${ }^{1}$ Department of Mathematics and Science Education, Faculty of Education, Kastamonu University, Turkey \\ ${ }^{2}$ Social Assistance and Support Foundation, Turkey
}

Copyright $\bigcirc 2017$ by authors, all rights reserved. Authors agree that this article remains permanently open access under the terms of the Creative Commons Attribution License 4.0 International License

\begin{abstract}
This research aims to compare the effects of Jigsaw technique from the cooperative learning methods and traditional learning method on laboratory material recognition and usage skills of students in General Physics Lab-I Course. This study was conducted with 63 students who took general physics laboratory-I course in the department of science education at a state university in Turkey during 2012-2013 academic year. The randomly selected class 1-A consisting of 32 students was assigned as the experiment group (jigsaw group) and the class 1-B consisting of 31 students was assigned as the control group for the study. The Material Recognition and Usage Skills Test (MRUST), Laboratory Skills Evaluation Test (LSET) and Jigsaw Opinion Scale (JOS) were applied. The results were analyzed by SPSS and frequencies were calculated and independent sample $t$-test was performed. When the analyses of the study were evaluated, it was concluded from the comparison of the experiment group, to which jigsaw technique was applied, and the control group, where traditional learning method was used, that the laboratory skills of the experiment group developed more than that of the control group. Moreover, according to the results of the opinion scale only applied to jigsaw group at the end of the study, it was found that the jigsaw technique created a more effective learning environment in laboratory practices.
\end{abstract}

Keywords Cooperative Learning, Jigsaw Technique, Laboratory, Recognition and Usage Skill

\section{Introduction}

As an individual, each student's abilities, learning styles, thinking styles, motivation levels and interests differ from each other. It will be facilitated to provide each student with unique education through their acquiring of the "learning to learn" skill, which is a necessity of both modern educational system and science education involving different scientific process skills. Using student-centered instructional methods and techniques to "teach students to learn" in modern educational systems will help students' knowledge to be permanent, and thus it will aid them to reflect this knowledge on their daily lives [1].

The constructivist perspective on learning is now widely accepted. Learning is an active process that takes place in the mind of the learner, and during which information from sources in the environment is re-interpreted in terms of existing knowledge and understanding. Whilst there are certainly differences in emphasis-for example, in the extent to which knowledge construction should be seen as an inter-personal rather than just an intra-personal activity it is generally accepted that meaningful learning requires the student to make sense of new information in terms of existing 'cognitive structure'. The overwhelming evidence for this type of approach is the vast literature on students' alternative conceptions in science, which demonstrates that 'understanding differently' is as likely an outcome of teaching as understanding-as intended or indeed not understanding (i.e., not making any sense of the presentation) $[2,3]$.

The advancement of societies depends upon the new generations' receiving a high quality education appropriate for the needs of the era. Modern education approach has led the teacher to face the responsibility of choosing the instructional method, which will achieve learning at the maximum level [4]. Therefore, teachers and teacher candidates who are responsible for education and instruction should innovate themselves continuously, asking the question "how can we achieve better learning?" to themselves, and thus they should try to utilize various methods and techniques.

Considering the fact that group achievements are at the forefront compared to individual achievements nowadays, 
students are required to be in solidarity with each other and contribute to each other's success. Cooperative learning, with its increasing number of applications all over the world with such an approach, is involves team work involving differing learning techniques in which students are responsible for both their team mates' and their own learning in small groups for a common purpose.

Cooperative learning methods are instructional techniques in which students work in small groups to help one another learn academic material. The use of these methods has been increasing rapidly in use at all instructional levels, from elementary school to college, and in every school subject [5].

Cooperative learning may be characterized as a learning approach in which students build small mixed groups in classroom and other environments to assist each other in learning a certain academic subject according to a common objective in which the individuals' self-confidence is encouraged and their communication and interaction are developed in which problem-solving and thinking capacity are enhanced and in which students participate in learning process actively and teach something each other [6-24]. In this study, jigsaw technique of cooperative learning method was used.

\subsection{Jigsaw Technique}

The jigsaw cooperative learning structure enhances cooperative learning by making each student responsible for teaching some of the material to the group. In this structure, students are members of two different groups, the 'home group' and the 'jigsaw group'. Initially, students meet in their home groups and each member of the group is assigned a portion of the material to learn as an 'expert' [5]. The home groups then break apart, like pieces of a jigsaw puzzle, and students move into jigsaw groups, which consist of members from the other home groups who have been assigned the same portion of the material. While in the jigsaw groups, the students discuss their particular material to ensure that they understand it. Students then return to their home groups, where they teach their material to the rest of their group [25, 26].

The jigsaw strategy, developed by Elliot Aronson, is a group-work method for learning and participating in group learning activities. It is a cooperative learning strategy that enables each student of a group to specialize in one aspect of a learning unit to resolve a task or class Project [27-29]. Aronson and his post-graduate students observed classes with a typical competitive environment had effects of enmity among people, and thus jigsaw method emerged as a result of the need to transform competitive environment into collaboration [30]. The method has become the most frequently used method of collaborative learning, for it possessed a very flexible structure with its many different applications. With the aim of making the design of successful collaborative learning environment easier, theorists introduced the method also known as "joining the parts" which encourages unity besides being dependent upon the definitions of collaborative learning and including individual responsibility [31]. Aronson emphasizes that the jigsaw method encourages students to listen, cooperate and exchange ideas. Jigsaw, a technique of collaborative learning method, is used to increase students' education and social performances. Today, jigsaw model has an increasing number of applications in academic level. For instance, poly-technique institutions in Mexico decided to use a jigsaw method based upon collaboration so as to instruct in various scientific areas [32]. In this study, the effects of jigsaw, a method of collaborative learning approach, was researched in general physics laboratory practices on science and technology teacher candidates' development of their laboratory skills besides recognizing and using the materials used in the laboratory. It was the aim of the study, with the aid of data obtained, at the end of the study to create a resource for new studies to be conducted regarding the training of teacher candidates.

Physics laboratory is one of the difficult concepts that students find difficult to grasp. It is argued here that cooperative learning and jigsaw technique improves learning as well as interactions among the students. Therefore it was thought that it would be beneficial for the students to teach through cooperative learning in order to increase their success in physics laboratory.

Physics education and its laboratory are becoming increasingly popular and important as they are seen as a means of improving scientific thinking, providing students with more experience of forming explanations and interpretations of their environment and with the capability of finding solutions to problems. This study investigates the effect of collaborative learning (jigsaw) versus traditional learning method on students' understanding of the students' laboratory material recognition and usage skills in general physics laboratory-I course. In recent years, research has focused on identifying and characterizing students' understanding of and difficulties with many topics in physics education.

\section{Method}

\subsection{Design of the Study}

In this study, the model of pre-test/post-test model with control group, which is one of empirical models for this study, was employed. The model of the study is summarized in Table 1. 
Table 1. The model of the study

\begin{tabular}{|c|c|c|c|c|}
\hline Groups & Pretests & Practice & Midtests & Posttests \\
\hline Experiment Group & $\begin{array}{c}\text { Materials Recognition and } \\
\text { Usage Skills Test }\end{array}$ & Jigsaw Technique & $\begin{array}{c}\text { Laboratory Skills } \\
\text { Evaluation Scale }\end{array}$ & $\begin{array}{c}\text { Materials Recognition and } \\
\text { Usage Skills Tests } \\
\text { Jigsaw Opinion Scale }\end{array}$ \\
\hline Control Group & $\begin{array}{c}\text { Materials Recognition and } \\
\text { Usage Skills Test }\end{array}$ & $\begin{array}{c}\text { Traditional Laboratory } \\
\text { Learning Method }\end{array}$ & & $\begin{array}{c}\text { Materials Recognition and } \\
\text { Usage Skills Test }\end{array}$ \\
\hline
\end{tabular}

\subsection{Research Group}

The research group of this study consisted of 63 students from two different classes enrolled in general physics laboratory-1 course during the 2012-2013 academic years in the department of science education at a state university in Turkey. One of the classes was defined as the non-jigsaw (control) group ( $n=31)$ and received education by traditional learning method, while the jigsaw (experimental) group $(n=32)$ was taught by cooperative learning (jigsaw). Pre-testing was performed for equivalent to one of the groups, in terms of academic knowledge. As seen from this range of marks it could be accepted that students participated in this study have similar academic achievement.

The experiments in the experiment guide [33] which involved general physics laboratory-1 course at the department of science education was examined.

\subsection{Data Collection Tools}

The data collection tools used in the study are explained in this section.

\subsubsection{Material Recognition and Usage Skills Test (MRUST)}

The MRUST was developed by the authors. The MRUST was composed of two parts. The first part of the test was prepared to detect whether the students recognized the materials used in the experiment, and the second part was prepared to specify for what aim the materials were used in the related experiment. The MRUST involved the materials used in the laboratory for the current experiments related to the general physics laboratory- 1 course. At the first stage, the participants were asked to write down 25 pieces of physics laboratory materials, and at the second stage the students were requested to write down the usage areas of the same materials. In this test, the questions in both stages were scored equally and each test was evaluated over 100 points. For the validity of MRUST developed, opinions of the physics lecturers and researchers on the subject have been taken into consideration. Researchers have pointed out that the gains of MRUST related to the experiment of general physics laboratory-I have been high towards measurement. The MRUST was applied once as pre-test to the students constituting both the control and the experiment group. Subsequent to the laboratory practice, the same test was applied once more.

\subsubsection{Laboratory Skills Evaluation Scale (LSES)}

This scale is in the form of a checklist prepared to detect whether the behavior changes to be sought occurred in the students during the experiment in measuring the students' laboratory skills while the experiments are being conducted $[34,35]$. It was attempted to specify the impact of collaborative learning methods used in laboratory practices on the students' performances with the use of this scale. This scale was taken from [35]. The scale was composed of four main headings; pre-preparation, preparing the experimental set-up, making the experiment and reporting the experiment, respectively. All parts were likert type and classified as 5: very good, 4: good, 3: average, 2 : poor and 1 : very poor. The LSES was applied to the experiment group so as to detect the effect of collaborative jigsaw method on the students' laboratory skills while the experiment was being made.

\subsubsection{Jigsaw Opinion Scale (JOS)}

This scale was merely applied to the students in the experiment group whom the jigsaw, a method of collaborative learning, was applied at the end of the study. This scale consists of two open-ended questions. Here, the students were requested to write it is implied their positive or negative opinions about the application of jigsaw technique in the laboratory and it was prepared to detect the deficiencies to occur during the practice. Only the students in the experiment group were applied JOS at the end of the laboratory practice with the aim of determining their ideas on the collaborative jigsaw method.

\subsection{Process}

The subjects in both groups took the "general physics laboratory-I" course for six weeks (two hours per week). The teaching in both groups was carried out by the authors. "Jigsaw technique" was applied to the experiment group while "traditional learning method" was applied to the control group. As indicated in Figure 1, the student in the jigsaw group were divided into six main groups since general physics laboratory-I is divided into six experiments. These experiments are (EXP.-1) Speed and Acceleration, (EXP.-2) Free Fall, (EXP.-3) Inertia and Gravitational Masses, (EXP.-4) Coefficient of Kinetic Friction, (EXP.-5) Simple Harmonic Motion, (EXP.-6) Simple Pendulum. While four main groups consisted of five students, the other two groups consisted of six students. Modules EXP.-1, EXP.-2, EXP.-3, EXP.-4, EXP.-5 and EXP.-6. 

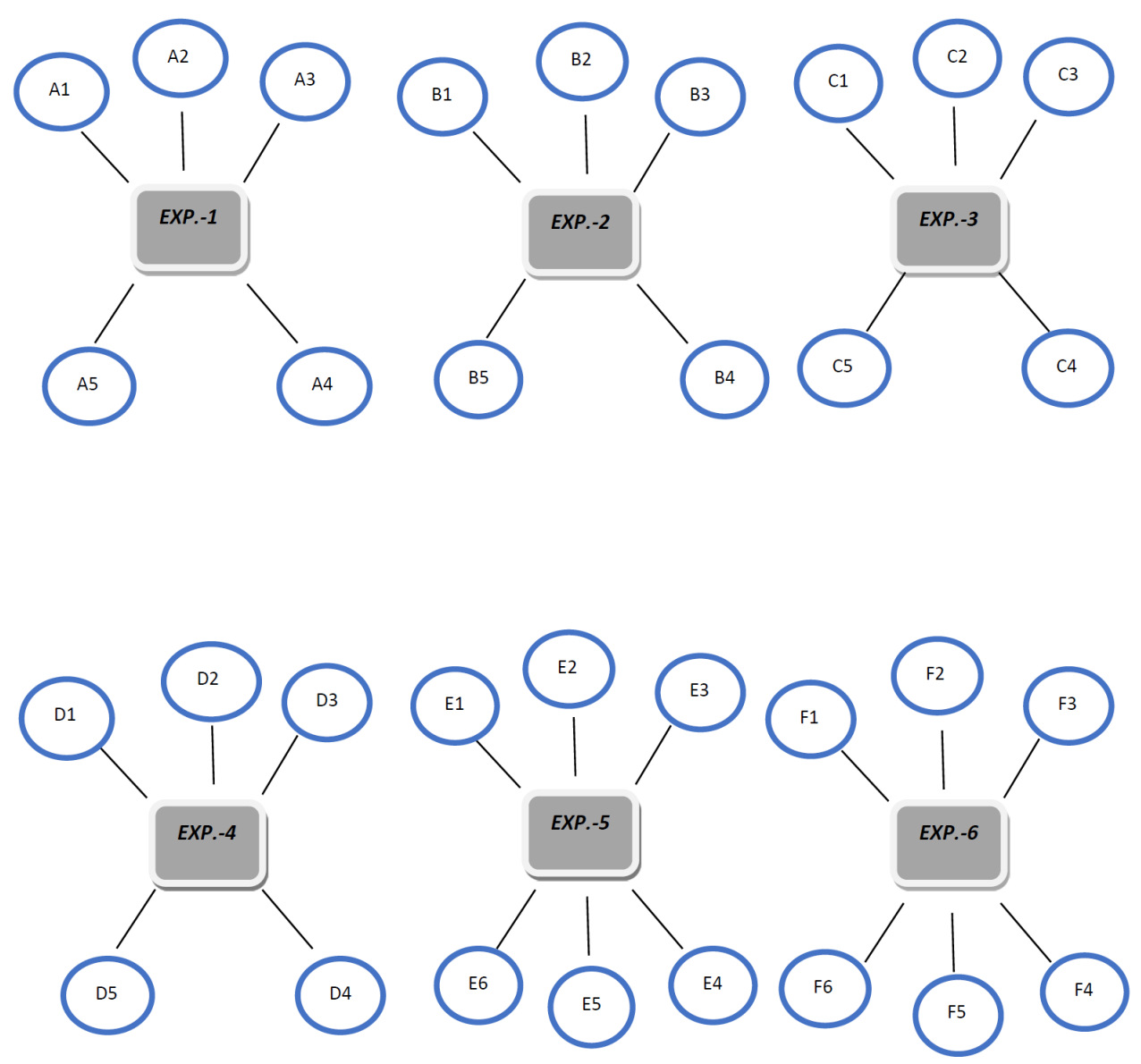

Figure 1. Main Groups Formed for Each Experiment

These modules are described below:

- Main group EXP.-1: The student in EXP.-1 prepared the subjects speed, average speed, acceleration, average acceleration and displacement and presented them in the class.

- Main group EXP.-2: The student in EXP.-2 prepared and presented the subjects acceleration of gravity, first speedless motion, relation of gravity to mass, gravitational force and constant acceleration.

- Main group EXP.-3: The student in EXP.-3 prepared and presented the subjects inertia scales, period and frequency, inertial mass, gravity and graphic drawing.

- Main group EXP.-4: The student in EXP.-4 prepared and presented the subjects coefficient of kinetic friction, coefficient of static friction, inclined plane, force and its components and frictional force.

- Main group EXP.-5: The student in EXP.-5 prepared and presented the subjects spring and spring constant, recall force, simple harmonic motion, period and frequency and elongation.

- Main group EXP.-6: The student in EXP.-6 prepared and presented the subjects simple harmonic motion, period and frequency, acceleration of gravity, small angle concept and graphic drawing.
Each main group studied their subject, presented their work in the classroom and discussed it with class. During the discussion time, the main group answered the questions coming from the class. The main groups then broke apart, like pieces of a jigsaw puzzle [3, 36], and students moved into jigsaw groups consisting of members from the other main groups who had been assigned the same of the material. Following the presentation of all subtopics of experiments, one student from each home group was selected to form jigsaw groups as illustrated in Figure 2.

While three jigsaw groups consisted of six students, the other two groups consisted of seven students. In these jigsaw groups, the members were asked to familiarize themseves with their subtopics. As these jigsaw groups understood the subtopic, each jigsaw group had to prepare a teaching strategy that its members could use to explain their subtopic to the rest of the class. Each jigsaw group presented their own topic, and then discussed the related topics. The students then went back into their home groups and were called "expert students". The experts were now in charge of teaching their specific subtopic to the rest of the students in their group. Once the teaching was completed, the MRUST was applied to both jigsaw and non-jigsaw groups following the presentation of the subject of general physics laboratory-I. The data obtained were evaluated by SPSS. 

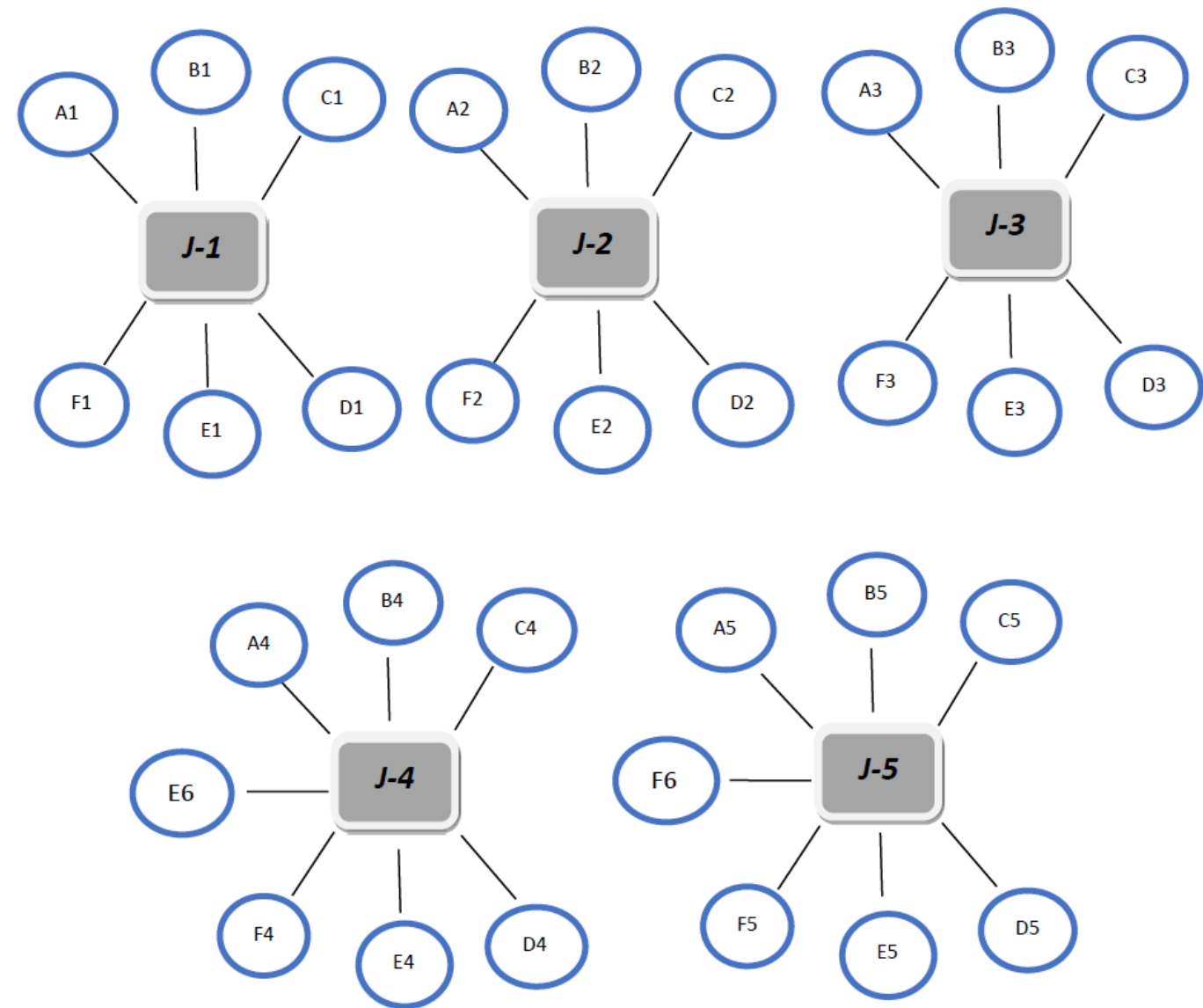

Figure 2. Forming Jigsaw Groups from the Main Groups

Table 2. Pre-Test and Post-Test Data of the Physics Laboratory Material Recognition Skills Test Scores

\begin{tabular}{|c|c|c|c|c|c|c|}
\hline Tests & Groups & $n$ & $\bar{x}$ & $S D$ & $t$ & $p$ \\
\hline \multirow{2}{*}{ Pre-test } & Experiment & 32 & 30.58 & 8.103 & \multirow{2}{*}{-0.98} & \multirow{2}{*}{0.332} \\
\hline & Control & 31 & 29.03 & 5.930 & & \\
\hline \multirow{2}{*}{ Post-test } & Experiment & 32 & 79.63 & 9.979 & \multirow{2}{*}{-19.61} & \multirow{2}{*}{0.003} \\
\hline & Control & 31 & 41.03 & 6.019 & & \\
\hline
\end{tabular}

\subsection{Analysis of the Data}

In this section, the analysis of the data obtained subsequent to the study, findings and comments on the findings are given. In the analysis of the MRUST pre-test and post-test used in order to detect the effect of the method used in the study upon material recognition and usage, paired samples t-test was applied and meaningfulness level was regarded as .05. LSES which was used as the mid-test and JOS which was applied to the experiment group as the post-test and which measured the students' opinions on the method were evaluated quantitatively and qualitatively. The data obtained were analyzed using SPSS package program and interpreted.

\section{Findings and Discussion}

The pre-test and post-test data obtained from MRUST and the independent t-test analysis of these data are given in Table 2 and Table 3 . When Table 2 is examined, it is seen that average scores of pre-test of both groups are nearly the same $\left(\overline{\mathrm{x}}_{\text {cont }}=29.03 ; \overline{\mathrm{x}}_{\text {exp }}=30.58\right)$. In addition, as $(\mathrm{t}=-0.98$; $\mathrm{p}=.332) \mathrm{p}>.05$, there is not a meaningful difference between the scores of two groups in the material recognition pre-test.

When the average scores of post-test given in Table 2 are viewed $\left(\overline{\mathrm{X}}_{\text {cont }}=41.03 ; \overline{\mathrm{X}}_{\mathrm{exp}}=79.63\right)$, there is a significant difference between the groups. Besides, as $(\mathrm{t}=-19.61 ; \mathrm{p}=.003)$ $\mathrm{p}<.05$, there is a meaningful difference in the material recognition post-test scores between two groups in favor of the experiment group.

On examining Table 3 , there is a slight difference between the pre-test scores of both groups $\left(\overline{\mathrm{X}}_{\text {cont }}=16.77 ; \overline{\mathrm{X}}_{\mathrm{exp}}=20.38\right)$; however, as $(\mathrm{t}=-1.24 ; \mathrm{p}=.223) \mathrm{p}>.05$, there is not a meaningful difference between the material usage pre-test scores of both groups. 
Table 3. Pre-Test and Post-Test Data of the Physics Laboratory Material Usage Skills Test Scores

\begin{tabular}{|c|c|c|c|c|c|c|}
\hline Tests & Groups & $n$ & $\bar{x}$ & $S D$ & $t$ & $p$ \\
\hline \multirow{2}{*}{ Pre-test } & Experiment & 32 & 20.38 & 12.060 & \multirow{2}{*}{-1.24} & \multirow{2}{*}{0.223} \\
\hline & Control & 31 & 16.77 & 8.667 & & \\
\hline \multirow{2}{*}{ Post-test } & Experiment & 32 & 47.56 & 17.245 & \multirow{2}{*}{-5.06} & \multirow{2}{*}{0.006} \\
\hline & Control & 31 & 27.23 & 13.123 & & \\
\hline
\end{tabular}

Table 4. The Analysis of the Data Obtained from the Laboratory Skills Evaluation Scale

\begin{tabular}{|c|c|c|c|c|c|c|c|}
\hline \multirow{2}{*}{\multicolumn{2}{|c|}{ Skills }} & \multicolumn{6}{|c|}{ Experiments } \\
\hline & & \multirow{2}{*}{$\begin{array}{c}1 \\
3.72\end{array}$} & \multirow{2}{*}{$\begin{array}{c}2 \\
4.14\end{array}$} & \multirow{2}{*}{$\begin{array}{c}3 \\
3.86\end{array}$} & \multirow{2}{*}{$\begin{array}{c}4 \\
3.72\end{array}$} & \multirow{2}{*}{$\frac{5}{3.43}$} & \multirow{2}{*}{$\begin{array}{c}6 \\
3.72\end{array}$} \\
\hline \multirow{5}{*}{ Pre-Preparation } & Finding out whether the student has read the experiment beforehand & & & & & & \\
\hline & Saying the purpose of the experiment & 3.43 & 3.43 & 3.28 & 3.14 & 3.28 & 3.72 \\
\hline & Defining the concepts and principles in the experiment & 3.28 & 3.00 & 3.00 & 3.28 & 3.14 & 3.43 \\
\hline & Stages and reliability of the experiment & 3.57 & 3.43 & 3.57 & 3.28 & 3.14 & 3.57 \\
\hline & Making the materials necessary for the experiment ready & 4.14 & 3.72 & 3.72 & 4.14 & 3.72 & 4.43 \\
\hline \multirow{4}{*}{$\begin{array}{l}\text { Preparing the } \\
\text { experiment } \\
\text { setup }\end{array}$} & Recognizing and choosing the materials necessary for the experiment & 3.57 & 3.86 & 3.72 & 3.72 & 3.43 & 3.86 \\
\hline & $\begin{array}{l}\text { Taking necessary precautions while setting up the experiment and after } \\
\text { the experiment }\end{array}$ & 4.14 & 4.14 & 4.00 & 3.71 & 4.14 & 4.28 \\
\hline & Setting up the experiment & 4.00 & 3.85 & 4.14 & 3.72 & 4.00 & 3.86 \\
\hline & Setting up the experiment in the reasonable time period & 3.86 & 3.57 & 4.14 & 3.71 & 3.85 & 4.00 \\
\hline \multirow{7}{*}{$\begin{array}{l}\text { Making the } \\
\text { experiment }\end{array}$} & $\begin{array}{l}\text { Following the steps of the experiment depending on the features of the } \\
\text { experiment }\end{array}$ & 3.86 & 3.57 & 3.86 & 3.85 & 3.57 & 4.14 \\
\hline & The ability of cooperating with experiment mates & 4.14 & 4.57 & 4.28 & 4.14 & 4.14 & 4.43 \\
\hline & Using the tools carefully and neatly & 4.28 & 4.43 & 4.43 & 4.14 & 4.28 & 4.72 \\
\hline & Keeping the experiment table neat and clean & 4.57 & 4.57 & 4.57 & 4.28 & 4.14 & 4.72 \\
\hline & Using the tools within sensitivity limits & 3.28 & 3.43 & 3.28 & 3.43 & 3.00 & 3.43 \\
\hline & Accomplishing the experiment tolerantly within the set time limit & 3.72 & 3.72 & 4.00 & 3.43 & 3.57 & 3.43 \\
\hline & Cleaning the tools used in the experiment and putting them back & 4.43 & 4.57 & 4.43 & 4.57 & 4.28 & 4.57 \\
\hline \multirow{4}{*}{$\begin{array}{l}\text { Reporting the } \\
\text { experiment }\end{array}$} & Is the name and date of the experiment written? & 4.72 & 4.72 & 4.72 & 4.85 & 4.43 & 4.86 \\
\hline & The names of the tools and materials used in the experiment & 4.72 & 4.72 & 4.72 & 4.85 & 4.57 & 4.71 \\
\hline & Is a table or diagram included where the measured values are shown? & 4.00 & 4.43 & 4.00 & 4.00 & 3.72 & 4.28 \\
\hline & Is the demanded result achieved in the experiment? & 3.72 & 4.14 & 3.72 & 3.43 & 3.43 & 3.72 \\
\hline
\end{tabular}

On viewing Table 3 , there is a significant difference between the average scores of post-test of both groups $\left(\overline{\mathrm{X}}_{\text {cont }}=27.23 ; \overline{\mathrm{X}}_{\mathrm{exp}}=47.56\right)$. Moreover, as $(\mathrm{t}=-5.06 ; \mathrm{p}=.006)$ $\mathrm{p}<.05$, there is a meaningful difference in favor of the experiment group between the material usage post-test scores of both groups.

LSES was applied only to the experiment group as a mid-test every week with the purpose of detecting the effect of collaborative jigsaw method upon the stages of the experiments. The arithmetical averages of the scores obtained are presented in Table 4.
When the data in Table 4 are observed, it is seen that the students' average scores in the main skills of pre-preparation, preparing the experiment set-up, making the experiment, reporting the experiment and also the subskills related to them are over the average score (3). It points out that the collaborative jigsaw method contributed positively to the process of making the experiment.

It is attempted to contribute to future practices by gathering the students' positive and negative ideas on the application with the use of the jigsaw opinion scale which was applied only to the experiment group. The results related to the students' opinions are given in Tables 5-6. 
Table 5. Analysis Results of the Positive Opinions from the Jigsaw Opinion Scale

\begin{tabular}{|c|c|c|}
\hline Positive Opinions & $f$ & $\%$ \\
\hline The existence of a teammate who had made the experiment before makes it easy for us to experiment & 10 & 33.3 \\
\hline Our teammate who had made the experiment before ensures the correction of our misinformation & 5 & 16.7 \\
\hline The existence of a teammate who had made the experiment before reduces the margin of error during the experiments & 7 & 23.3 \\
\hline It enables exchange of ideas among our teammates & 9 & 30.0 \\
\hline It reduces the duration of the experiment & 10 & 33.3 \\
\hline It makes us achieve better results through cooperation & 2 & 6.7 \\
\hline It makes us learn better & 6 & 20.0 \\
\hline It increases the possibility of the teacher's being interested in each student & 1 & 3.3 \\
\hline The dependence of the students upon the teacher is lessened & 1 & 3.3 \\
\hline Our teammate who had made the experiment before enables the completion of our imperfect information about the experiment & 6 & 20.0 \\
\hline Our teammate who had made the experiment before makes it easy for us to understand the experiment & 8 & 26.7 \\
\hline Everyone in the group shares the responsibility & 2 & 6.7 \\
\hline It makes the experiment to be more organized & 2 & 6.7 \\
\hline It makes the ideas within the group to be discussed more positively & 1 & 3.3 \\
\hline It lessens the unnecessary burden of the teacher even if only slightly & 1 & 3.3 \\
\hline It encourages students to make experiments & 1 & 3.3 \\
\hline We do not encounter any uproar during the experiments we make for the first time & 1 & 3.3 \\
\hline When one makes something wrong, he/she is criticized and corrected easily & 2 & 6.7 \\
\hline We achieved better results by cooperating & 1 & 3.3 \\
\hline Thanks to our teammate who had made the experiment beforehand, we had a good command of the experiment & 1 & 3.3 \\
\hline
\end{tabular}

*Some students expressed more than one opinion.

Table 6. Analysis Results of the Negative Opinions from the Jigsaw Opinion Scale

\begin{tabular}{|c|c|c|}
\hline Negative Opinions & $f$ & $\%$ \\
\hline It hindered individual learning & 1 & 3.2 \\
\hline The misleading of our teammate who had made the experiment caused us to make it wrong. & 2 & 6.5 \\
\hline Our teammate's too quickly performing who had known the experiment makes our learning difficult & 1 & 3.2 \\
\hline The experiment lasts too long as the group is crowded & 1 & 3.2 \\
\hline Conflicts occur sometimes among us. & 2 & 6.5 \\
\hline Rarely some members do not fulfill their responsibility & 5 & 16.1 \\
\hline The existence of a teammate who had made the experiment beforehand resulted in others being unprepared & 2 & 6.5 \\
\hline Lack of knowledge of our teammate who knows the experiment affects us negatively & 3 & 9.7 \\
\hline
\end{tabular}

*Some students expressed more than one opinion.

On examining Table 5 , it is seen that $33.3 \%$ of the students stated experiment practices became easier, $16.7 \%$ of them stated their misinformation was all corrected, $23.3 \%$ of them stated the number of errors made during the experiments decreased, $30 \%$ of them expressed there was an exchange of knowledge, $30 \%$ of the students expressed the duration of the experiment was lessened, and $6.7 \%$ of them stated cooperating resulted in success.

The students' negative opinions on the method applied are presented in Table 6 .

As seen on the Table $6,3.2 \%$ of the students stated it hindered individual learning, $6.5 \%$ of them stated sometimes the fixed member of the group misled the other group members during the experiment, $3.2 \%$ of them expressed it made the learning difficult as the member of the group who had made the experiment previously performed too quickly during the experiment, $3.2 \%$ of the students stated the experiment took longer in more crowded groups, $6.5 \%$ of them expressed there were conflicts within the group, $16.1 \%$ stated responsibility was not shared even if it happened rarely, $6.5 \%$ of them stated some members caused them to be unprepared for the experiment, and $9.7 \%$ expressed the insufficiency of the member who had made the experiment affected the other members of the group negatively.

\section{Conclusions}

As a conclusion of the pre-test data of both the experiment and the control group in which the skills of recognizing and 
using laboratory materials were measured, it was revealed that the students recognized some laboratory materials yet there was not a difference between the groups in view of both recognizing and using the tools. During the experiments where collaborative jigsaw method was applied to the experiment group and traditional learning group work method was applied to the control group without any intervention, the students used the laboratory materials and made the experiments about these materials. According to the post-test data of both groups, the reason for the fact that the students' test scores in the experiment group were higher than those of the students' in the control group regarding the skills of recognizing and using laboratory materials may be attributed to the fact that the students in the collaborative jigsaw method group selected the tools from the cupboard where the experiment tools were located untidily and used them with the help of a teammate who had made the experiment beforehand and that a teammate who had experienced the experimenting process before assisted his/her friends in the group with theoretical knowledge and the practice. The results obtained are similar to those of different studies [37, 38, 39]. LSES which was used as the mid-test was applied so as to observe the basic skills of the students in the collaborative group during the application steps of the experiment. Therefore, it was found as a result of the evaluation that the collaborative jigsaw method affected the process of experiment-making in the positive way.

The students' positive and negative opinions were also determined regarding the collaborative jigsaw method which was applied to a research sample each of whom were teacher candidates. On examining the students' positive opinions in Table 5, it is understood that in general terms the students expressed their ideas better as a result of cooperation and an environment where they could discuss ideas easily was created. It was revealed thanks to the students' opinions that in a laboratory environment where the teacher's efficiency increased in the class and the teacher's accessibility became easier for unsolved problems; any deficiency of learning resulting from uproar disappeared. It was concluded that the students' motivation in experiments increased as a result of cooperation, and since lack of information and practical errors were corrected by group members in solidarity and by attributing the feeling of accomplishment. When the studies conducted by $[1,23,24,29,40-45]$ are viewed, the results obtained support the results of this study. According to these conclusions, it may be said that specifically jigsaw technique and generally cooperative learning method have positive effects on student success and participation in laboratory in learning and making the physics experiments.

In conclusion, this method will be beneficial for both the academic success of the students and the elimination of misconceptions about particular subjects, and it will make students more active. The fact that students in the jigsaw groups gave more correct answers to the open-ended questions demonstrates that students had the chance to contribute their knowledge on the subjects as they did research and benefited from previous research, and they took part in the learning process actively in both in-class and out-of-class discussions [3].

As a result, the subdivision of the subjects of general physics laboratory-I, where the jigsaw class was divided first into home groups then into jigsaw groups, and the fact that the research and presentation of these subjects was done by these groups resulted in both greater academic success among the students and the greater reduction of misconceptions about experiment of physics via a better understanding of the subject. The evaluation of the JOS showed that the jigsaw method is an active method for improving students' understanding of the subject.

Since the education provided in the laboratory is based upon practice and teachers may experience difficulty in reaching students, it may be enabled for all students to obtain knowledge simultaneously thanks to the use of jigsaw technique. Besides the fact that members should be informed about their responsibilities, those who do not fulfill their responsibility should be detected and necessary precautions should be taken in crowded groups where jigsaw technique is applied. The groups to which jigsaw technique is applied should be given sufficient amount of time and the required opportunities should be provided for pre-preparation. Any lack of tools and materials necessary for experiment setup should be completed and thus it should be prevented for students to face any problems during the experiment. It is not recommended for very crowded classes to apply jigsaw technique due to the difficulty in controlling the class.

\section{Acknowledgements}

This research was financially supported by Kastamonu University Scientific Research Projects Coordination Unit (Project No: KUBAP-01/2013-25).

\section{REFERENCES}

[1] Şenol, H., Bal, Ş., \& Yıldırım, H. İ. (2007). İlköğretim 6. sınıf fen bilgisi dersinde duyu organları konusunun işlenmesinde işbirlikli öğrenme yönteminin öğrenci başarısı ve tutum üzerine etkisi [the effect of cooperative learning on pupils' success and attitudes against science and teaching sensory organs at 6th grade]. Kastamonu Eğitim Dergisi, 15(1), 211-221.

[2] Taber, K. S. (2001). Building the structural concepts of chemistry: Some considerations from educational research. Chemistry Education: Research and Practice in Europe, 2(2), 123-158.

[3] Doymus, K. (2008). Teaching chemical bonding through jigsaw cooperative learning. Research in Science \& Technological Education, 26(1), 47-57.

[4] Acar, A. (2006). İşbirliğine dayalı öğrenme yönteminin ortaöğretim coğrafya dersi yerleşme konusunun 
öğretilmesinde başarıya etkisi [The effect of cooperative learning method and achievement of teaching the settlement issues in secondary geography course] (Master's thesis, Gazi University, Ankara, Turkey). Retrieved from https://tez.yok.gov.tr/UlusalTez/Merkezi/

[5] Slavin, R. E. (1991). Cooperative learning and group contingencies. Journal of Behavioral Education, 1(1), 105115 .

[6] Bolling, A. (1994). Using group journals to improve writing and comprehension. Journal on Excellence in College Teaching, 5(1), 47-55.

[7] Bowen, C. W. (2000). A quantitative literature review of cooperative learning effects on high school and college chemistry achievement. Journal of Chemical Education, 77(2), 116-119.

[8] Carol, A. (1988). High school graduates in entry level jobs. What do employers want? New York: Reproduction Service (ED No: 293972).

[9] Coppola, B. P., \& Lawton, R. G. (1995). Who has the some substance that I have? A blueprint for collaborative learning activities. Journal of Chemical Education, 72, 1120-1122.

[10] Eilks, I. (2005). Experiences and reflections about teaching atomic structure in a jigsaw classroom in lower secondary school chemistry lessons. Journal of Chemical Education, $82(2), 313-319$

[11] Gardener, B. S., \& Korth, S. D. (1996). Using reflection in cooperative learning groups to integrate theory and practice. Journal on Excellence in College Teaching, 7(1), 17-30.

[12] Gillies, R. M. (2006). Teachers and students verbal behaviors during cooperative and small-group learning. British Journal of Educational Psychology, 76(2), 271-287.

[13] Hall, O. A., \& Paolucci, B. (1972). Teaching home economics. New York: John Wiley \& Son, Inc.

[14] Hennessy, D., \& Evans, R. (2006). Small-group learning in the community college classroom. The Community College Enterprise, 12(1), 93-109.

[15] Imel, S. (1989). Employers' expectations of vocational education. Columbus, Ohio: ERIC Clearinghouse on Adult, Career and Vocational Education (ERIC Document Production Service No. ED 318912).

[16] Kerka, S. (1990). Job related basic skills. Columbus, Ohio: ERIC Clearinghouse on Adult, Career, and Vocational Education (ERIC Document Production Service No. ED 318912).

[17] Levine, E. (2001). Reading your way to scientific literacy. Journal of College Science Teaching, 31(2), 122-125.

[18] Lin, E. (2006). Learning in the science classroom. The Science Teacher, 73(5), 35-39.

[19] Parker, R. (1985). Small-group cooperative learning in the classroom. Oregon School Study Council Bulletin, 27(7), 128.

[20] Prichard, J. S., Bizo, L. A., \& Stratford, R. J. (2006). The educational impact of team-skills training: Preparing students to work in groups. British Journal of Educational Psychology, 76(1), 119-140.
[21] Prince, M. (2004). Does active learning work? A review of the research. Journal of Engineering Education, 93(3), 223-231.

[22] Slavin, R. E. (1991). Are cooperative learning and untracking harmful to the gifted? Educational Leadership, 48, 68-71.

[23] Şimşek, Ü. (2007). Çözeltiler ve kimyasal denge konularında uygulanan jigsaw ve birlikte öğrenme tekniklerinin öğrencilerin maddenin tanecikli yapıda öğrenmeleri ve akademik başarıları üzerine etkisi [The effects of the Jigsaw and learning together techniques applied in solutions and chemical equilibrium subjects on learning of the particulate nature of matter by the students and their the academic achievements] (Doctoral dissertation, Atatürk University, Erzurum, Turkey). Retrieved from https://tez.yok.gov.tr/UlusalTez/Merkezi/

[24] Maden, S. (2011). Effect of jigsaw I technique on achievement in written expression skill. Educational Sciences: Theory \& Practice, 11(2), 911-917.

[25] Clarke, J. (1999). Pieces of the puzzle: the jigsaw method. In Handbook of cooperative learning methods, ed. S. Sharan. Westport, CT: Preager.

[26] Colosi, J. C., \& C. R. Zales (1998). Jigsaw cooperative learning improves biology lab course. Bioscience, 48(2), 11824.

[27] Aronson, E. (1990). Applying social psychology to desegregation and energy conservation. Personality and Social Psychology Bulletin, 16, 118-132.

[28] Aronson, E., \& Patnoe, S. (1996). The jigsaw classroom: Building cooperation in the classroom, New York, Addison Wesley Longman.

[29] Maftei, G., \& Popescu, F. F. (2012). Teaching atomic physics in secondary school with the jigsaw technique. Romanian Reports in Physics, 64(4), 1109-1118.

[30] Reese, S. (2009). The Jigsaw Classroom. Techniques, 84(4), 8-9.

[31] Weidman, R., \& Bishop, M. J. (2009). Using the jigsaw model to facilitate cooperative learning in an online course. Quarterly Review of Distance Education, 10(1), 51-64.

[32] Fini, A. S., Zarei, E., \& Sardare, M. S. (2014). The comparison between the effect on jigsaw 2 and traditional teaching methods on educational achievement. World of Researches Publication, 3(1), 22-26.

[33] Şahan, B. Y. (1999). Fizik laboratuvar deneyleri (mekanik-elektrik-optik-dalgalar) [Physics laboratory experiments (mechanical-electrical-optical -waves)]. Sürat Yayınları, İstanbul

[34] Tekin, H. (2004). Eğitimde Ölçme ve Değerlendirme [measurement and evaluation in education]. Ankara: Yarg1 Yayınevi.

[35] Aksoy, G. (2006). İşbirlikçi öğrenme yönteminin genel kimya laboratuvarı dersinde akademik başarıya, laboratuvar malzemesi tanıma ve kullanma becerisine etkisi [The effect of cooperative learning on students' achivements, identifications and use of laboratory equipments in general chemistry laboratory course] (Master's thesis, Atatürk University, Erzurum, Turkey). Retrieved from https://tez.yok.gov.tr/UlusalTez/Merkezi/ 
[36] Goodwin, L., Miller, J. E. \& Cheetham, R. D. (1991). Teaching freshmen to think - does active learning work. BioScience, 41(10), 719-22.

[37] Yaman, S., \& Öner, F. (2003). Lise fizik laboratuvarlarında kullanılan araç-gereçlerin yeterlilik düzeyleri ve laboratuvar çalışmalarının değerlendirilmesi [Evaluation on laboratory works and qualification levels of used equipment at high school physics laboratory]. Gazi Üniversitesi Kastamonu Ë̆itim Dergisi, 11(2), 379-386.

[38] Duckworth, A. H. (2010). Cooperative learning: attitudes, perceptions, and achievement in a traditional, online, and hybrid instructional setting. (Order No. 3416278, The University of Southern Mississippi). ProQuest Dissertations and Theses, 182.

[39] Nama, C. W., \& Zellner, R. D. (2011). The relative effects of positive interdependence and group processing on student achievement and attitude in online cooperative learning. Computers \& Education, 56, 680-688.

[40] Sharan, S. (1980). Cooperative Learning in Small Groups: Recent Methods and Effects on Achievement, Attitudes, and Ethnic Relations. Tel-Aviv University Review of Education Research, 50(2), 241-271.

[41] Çil, E. (2005). İlköğretim fen bilgisi dersinde atomun yapısı ve periyodik çizelge konusunun takım oyun turnuva tekniği ve sunuş yöntemi ile öğretiminin öğrenci başarısı ve duyuşsal özellikleri üzerine etkisinin belirlenmesi [Investigation of the effects of teaching the structure of atom and periodic table through team game tournament technique and presentation method on the success of students and sensory features] (Master's thesis, Muğla University, Muğla, Turkey). Retrived from https://tez.yok.gov.tr/UlusalTez/Merkezi/

[42] Şengören, S. K. (2006). Optik dersi 1şıkta girişim ve kırınım konularının etkinlik temelli öğretimi: işbirlikli öğrenme yönteminin etkilerinin araştırılması [Activity based instruction of the interference and diffraction subjects of light in optics course: Investigation of the effects of the cooperative learning method] (Doctoral dissertation, Dokuz Eylül University, İzmir, Turkey). Retrieved from

https://tez.yok.gov.tr/UlusalTez/Merkezi/

[43] Tanel, R. (2006). Termodinamiğin ikinci yasası ve entropi konularının öğrenimine işbirlikli öğrenme yönteminin etkilerinin incelenmesi [Investigation of the effects of the cooperative learning method on understanding the second law of thermodynamics and Entropy] (Doctoral dissertation, Dokuz Eylül University, İzmir, Turkey). Retrieved from https://tez.yok.gov.tr/UlusalTez/Merkezi/

[44] Markic, S., \& Kirık, Ö. T. (2012). The self-efficacy of pre-service elementary teachers using cooperative learning in science teaching. Procedia-Social and Behavioral Sciences, $46,5005-5009$.

[45] Doymus, K. (2008). Teaching chemical equilibrium with the jigsaw technique. Res. Sci. Educ., 38, 249-260.

i This study was produced from the second author's master's thesis and a part of the study was presented at ISER 2014 World Conference as oral presentation in Turkey. 